\title{
Feasibility of Composting Combinations of Sewage Sludge, Cattle Manure, and Sawdust in a Rotary Drum Reactor
}

\author{
Ashish Kumar Nayak ${ }^{\dagger}$, Ajay S. Kalamdhad \\ Department of Civil Engineering, Indian Institute of Technology Guwahati, Guwahati, Assam 781039, India
}

\begin{abstract}
The aim of this paper was to study the effect of five different waste combinations (C/N 15, C/N 20, C/N 25, C/N 30, and control) of sewage sludge coupled with sawdust and cattle manure in a pilot scale rotary drum reactor, during 20 days of the composting process. Our results showed that $\mathrm{C} / \mathrm{N} 30$ possesses a higher temperature regime with higher \% reduction in moisture content, total organic carbon, soluble biochemical oxygen demand and chemical oxygen demand; and higher \% gain in total nitrogen and phosphorus at the end of the composting period implying the total amount of biodegradable organic material is stabilized. In addition, $\mathrm{CO}_{2}$ evolution and oxygen uptake rate decreased during the process, reflecting the stable behavior of the final compost. A Solvita maturity index of 8 indicated that the compost was stable and ready for usage as a soil conditioner. The results indicated that composting can be an alternate technology for the management of sewage sludge disposal.
\end{abstract}

Keywords: Composting, C/N ratio, Rotary drum, Sewage sludge, Stability

\section{Introduction}

The treatment and disposal of domestic and residential sludge is an environmentally responsive problem, because sludge possesses good fertilizer properties but may contain heavy metals, which might reduce productivity and cause environmental risks. Among various techniques, land filling is the primary alternative for sewage disposal. But the future of sludge disposal through land filling is not feasible due to the fact that a large volume of soil is required to cover the waste in order to prevent the leaching of potentially toxic compounds including metals and phenols [1]. In addition, sewage sludge has high nutritive value for plants and its application as an agricultural soil supplement is widely recommended. It accelerates the microbial respiration in cultivated land and enhances the crop production, as it is rich in nutrients and has higher organic content. However, the direct use of these wastes may cause new problems derived from the presence of heavy metals, pathogenic microorganisms, bad odors, or phytotoxic organic compounds [2]. Therefore, it should be stabilized, before it can be effectively disposed of in the natural environment. All of these problems can be overcome by a composting method, where all unwanted by-products can be reduced to an acceptable level [3].

Composting provides a cost-effective alternative treatment method for sewage sludge by decomposing organic matter, pro- ducing a stabilized residue, and disinfecting pathogens [4]. There are many factors that influence the composting process, such as the proportions of the mixture, aeration rate, oxygen consumption rates, compost recycling, moisture content, $\mathrm{pH}$ and carbonto-nitrogen $(\mathrm{C} / \mathrm{N})$, and so on [5]. Among them, the composition of an initial mixture that is optimized in terms of $\mathrm{C} / \mathrm{N}$ ratio is one of the important aspects affecting organic matter degradation and nitrogen losses during sludge composting [6]. In addition, sewage sludge cannot be composted alone due to initial higher moisture; and its compact behavior requires it to be mixed with dry materials, which act as bulking agent in order to absorb the moisture, thereby improving the aeration and the compost quality [7]. The organic fraction of cattle manure also plays an important role in increasing soil organic matter and tilth; improving soil structure and water infiltration by having the tendency to bind the substrates together. Therefore, the nature/type of sludge and proportion of bulking agent used for composting influences the composting reaction rate and the final compost quality. In the past literatures, sawdust has been proven to be a good bulking agent for sewage sludge composting and it has been widely used in studies on composting process [8]. Further studies aiming to determine the most suitable ratio for optimizing the performance of sludge composting are very scarce.

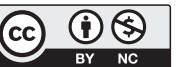

This is an Open Access article distributed under the terms of the Creative Commons Attribution Non-Commercial License (http://creativecommons.org/licenses/by-nc/3.0/) which permits unrestricted non-commercial use, distribution, and reproduction in any medium, provided the original work is properly cited.
Received September 27, 2013 Accepted January 15, 2014

${ }^{\dagger}$ Corresponding Author

E-mail: coco.ashish@gmail.com

Tel: +91-361-2582431 Fax: +91-361-2582440 
In contrast to conventional outdoor technologies, such as windrows and static piles, the rotary drum composter has been considered to be an efficient and promising technology, as it provides agitation, aeration and compost mixing in order to produce a consistent and uniform end product, without any odor or leachate related problems [5]. The composting time is drastically reduced to 2-3 weeks. The goal of the rotary drum composting technique is to stabilize the compost as rapidly as possible. Different types of wastes (cattle manure, swine manure, municipal bio-solids, brewery sludge, chicken manure, animal mortalities and food residues) can be effectively composted in rotary drums [9-12]. Until recently, the reported data about the use of rotary drums in sewage sludge composting are rather scarce [5].

In addition, stability refers to the extent to which readily biodegradable organic matter has decomposed [13]. Compost is considered unstable, if it contains a high proportion of biodegradable matter that may sustain high microbial activity. If the material contains mainly recalcitrant or humus-like matter, it is not able to sustain microbial activity, and therefore it is considered stable [13]. In simple words, the composting mass is considered "stable", when it has reached a state of decomposition at which it can be stored without giving rise to health or nuisance problems. Stability has been evaluated in terms of physical (temperature, aeration demand, odor, and color, etc.), chemical (volatile solids, $\mathrm{C} / \mathrm{N}$ ratio, chemical oxygen demand [COD], polysaccharides, humic substances, etc.), and biological characteristics (respiration, measured either as $\mathrm{O}_{2}$ consumption, $\mathrm{CO}_{2}$ production, or heat generation, etc.); but none has been found universal acceptance [14]. However, respirometric techniques are well suited for compost stability measurement [13-16]. Most of the studies on respirometric methods on compost stability are available for traditional composting techniques, such as windrows and static pile types. Information on the stability of compost in vessel techniques, especially rotary drum for the waste combinations based on different $\mathrm{C} / \mathrm{N}$ ratios, is rather limited. Hence, it is necessary to measure the stability to assess the composting process within rotary drum.

Therefore, the objective of this study is to perform a comparative investigation of the rotary drum composting process of sewage sludge coupled with cattle manure and sawdust in five different proportions, based on $\mathrm{C} / \mathrm{N}$ ratios $(15,20,25$, and 30$)$ and control, respectively. The present studies evaluate the dynamics of composting in terms of physicochemical, biological and stability analysis.

Table 1. Waste composition ${ }^{\mathrm{a}}$ and initial characteristics of waste materials

\begin{tabular}{|c|c|c|c|}
\hline \multirow{2}{*}{ Reactor/parameter } & \multicolumn{3}{|c|}{ Waste material (kg) } \\
\hline & Sewage sludge & Cattle manure & Sawdust \\
\hline $\mathrm{C} / \mathrm{N} 15$ & 130 & 16 & 4 \\
\hline $\mathrm{C} / \mathrm{N} 20$ & 104 & 39 & 7 \\
\hline $\mathrm{C} / \mathrm{N} 25$ & 98 & 39 & 13 \\
\hline $\mathrm{C} / \mathrm{N} 30$ & 87 & 45 & 18 \\
\hline Control & 150 & - & - \\
\hline Moisture content (\%) & $79.16 \pm 2.03$ & $80.77 \pm 0.04$ & $10.25 \pm 0.26$ \\
\hline $\mathrm{pH}$ & $6.03 \pm 0.01$ & $6.61 \pm 0.07$ & $6.16 \pm 0.01$ \\
\hline Electrical conductivity (dS/m) & $2.77 \pm 0.01$ & $3.28 \pm 0.21$ & $0.39 \pm 0.01$ \\
\hline Ash content $(\%)$ & $61.54 \pm 0.32$ & $29.88 \pm 3.85$ & $2.41 \pm 0.05$ \\
\hline Total organic carbon $(\%)$ & $21.37 \pm 0.18$ & $38.96 \pm 2.14$ & $54.22 \pm 0.03$ \\
\hline Total nitrogen $(\%)$ & $1.91 \pm 0.22$ & $1.47 \pm 0.20$ & $0.40 \pm 0.02$ \\
\hline Nitrate nitrogen $\left(\mathrm{NO}_{3}-\mathrm{N}\right)(\%)$ & $0.006 \pm 0.004$ & $0.045 \pm 0.036$ & ND \\
\hline Ammoniacal nitrogen $\left(\mathrm{NH}_{4}-\mathrm{N}\right)(\%)$ & $1.47 \pm 0.04$ & $0.54 \pm 0.02$ & $0.05 \pm 0.02$ \\
\hline Total phosphorous (\%) & $4.99 \pm 0.29$ & $4.29 \pm 0.26$ & $1.69 \pm 0.36$ \\
\hline Available phosphorus (\%) & $1.75 \pm 0.09$ & $2.76 \pm 0.12$ & $0.98 \pm 0.16$ \\
\hline $\mathrm{C} / \mathrm{N}$ ratio & $11.19 \pm 1.21$ & $26.44 \pm 2.50$ & $135.88 \pm 7.25$ \\
\hline $\mathrm{Na}$ (g/kg dry matter) & $1.03 \pm 0.28$ & $0.94 \pm 0.12$ & $0.55 \pm 0.09$ \\
\hline $\mathrm{K}$ (g/kg dry matter) & $4.83 \pm 0.35$ & $6.17 \pm 0.19$ & $1.95 \pm 0.05$ \\
\hline $\mathrm{Ca}$ (g/kg dry matter) & $2.03 \pm 0.34$ & $1.55 \pm 0.21$ & $0.80 \pm 0.17$ \\
\hline $\mathrm{Fe}$ (g/kg dry matter) & $1.18 \pm 0.29$ & $6.61 \pm 0.32$ & $2.19 \pm 0.08$ \\
\hline $\mathrm{Ni}$ (mg/kg dry matter) & $278.0 \pm 19.3$ & $231.5 \pm 11.4$ & $221.5 \pm 23.5$ \\
\hline $\mathrm{Cr}$ (mg/kg dry matter) & $198.5 \pm 0.4$ & $89.2 \pm 0.2$ & $124.5 \pm 0.5$ \\
\hline Mn (mg/kg dry matter) & $355.3 \pm 23.0$ & $496.1 \pm 17.5$ & $148.5 \pm 19.5$ \\
\hline Cd (mg/kg dry matter) & $37.0 \pm 2.8$ & $51.5 \pm 6.3$ & $58.0 \pm 4.3$ \\
\hline $\mathrm{Cu}(\mathrm{mg} / \mathrm{kg}$ dry matter) & $174.5 \pm 10.5$ & $45.5 \pm 9.0$ & $37.5 \pm 6.5$ \\
\hline $\mathrm{Pb}$ (mg/kg dry matter) & $130.1 \pm 8.0$ & $80.5 \pm 5.8$ & $155.0 \pm 4.5$ \\
\hline Zn (mg/kg dry matter) & $967.2 \pm 23.3$ & $124.3 \pm 11.5$ & $101.9 \pm 17.3$ \\
\hline Chemical oxygen demand (mg/L) & $692.5 \pm 21.8$ & $351.7 \pm 5.1$ & $1,196.8 \pm 10.3$ \\
\hline Biochemical oxygen demand (mg/L) & $278.4 \pm 14.6$ & $235.9 \pm 11.2$ & $731.4 \pm 15.7$ \\
\hline $\mathrm{CO}_{2}$ evolution (mg/g VS/day) & $12.1 \pm 0.5$ & $17.6 \pm 0.5$ & $10.8 \pm 0.1$ \\
\hline Oxygen uptake rate (mg/g VS/day) & $17.9 \pm 0.2$ & $21.8 \pm 1.3$ & $12.5 \pm 0.7$ \\
\hline
\end{tabular}

Values are presented as number or mean \pm standard deviation.

$\mathrm{C} / \mathrm{N}$ ratio: carbon-to-nitrogen ratio, ND: not detected, VS: volatile solids.

${ }^{a}$ Waste composition has been made based on wet weight basis by using the Cornell composting equation. 


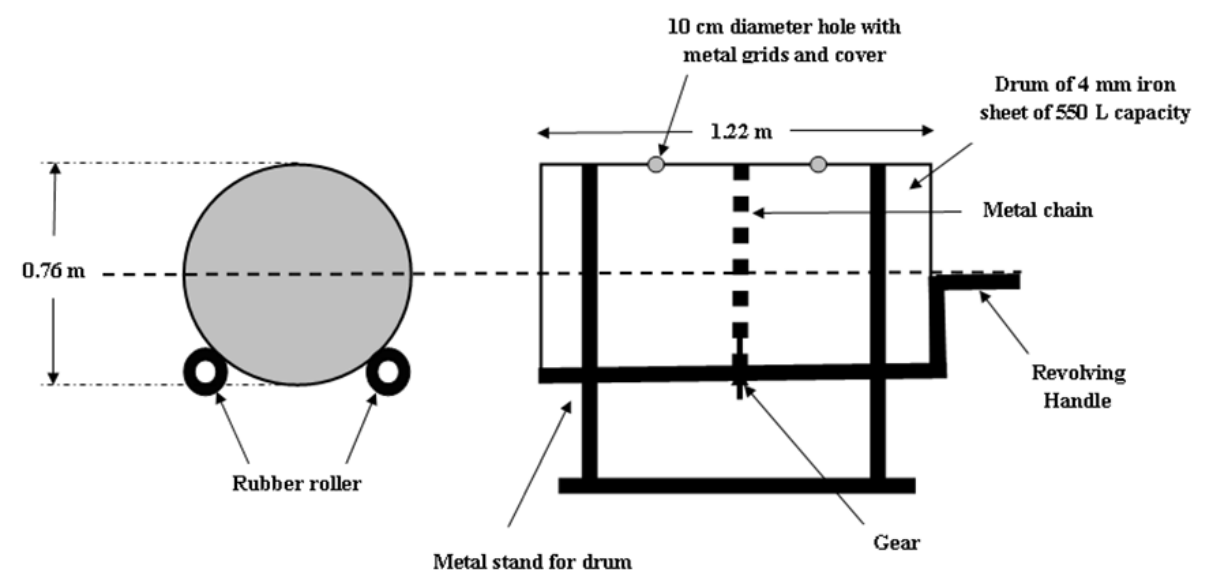

Fig. 1. Pilot scale rotary drum composter.

\section{Materials and Methods}

\subsection{Feedstock Materials and Its Preparation}

Sewage sludge, cattle manure, and sawdust were used for the preparation of different waste mixtures. Sewage sludge was procured from a sewage treatment plant at the Indian Institute of Technology Guwahati campus. The sewage sludge was dried in direct sunlight for 4-5 days with periodic turning to bring its moisture content to $70 \%$. Fresh cattle manure was obtained from nearby Amingaon village. Sawdust was purchased from the nearby rice mill and saw mill, respectively. The compost material was prepared by mixing different proportions (C/N 15, C/N 20, C/N $25, \mathrm{C} / \mathrm{N} \mathrm{30}$, and control) of the collected waste, as described in Table 1 . Since the nitrogen content is very high in sewage sludge in the range of $1.91 \%$ and it also contains higher amount of macro-nutrients, it can be successfully composted along with cattle manure and sawdust. The $\mathrm{C} / \mathrm{N}$ ratio of the compost mixture was calculated as follows in Eqs. (1)-(3) [17]:

$$
G=\frac{M_{1} \times Q_{1}+M_{2} \times Q_{2}+M_{3} \times Q_{3}}{Q_{1}+Q_{2}+Q_{3}},
$$

where $Q_{n}$ is mass of material $n$ (wet weight basis), $G$ is moisture goal (\%), and $M_{n}$ is moisture content (\%) of material $n$.

$$
R=\frac{Q_{1}\left(C_{1} \times\left(100-M_{1}\right)\right)+Q_{2}\left(C_{2} \times\left(100-M_{2}\right)\right)+Q_{3}\left(C_{3} \times\left(100-M_{3}\right)\right)+\ldots}{Q_{1}\left(N_{1} \times\left(100-M_{1}\right)\right)+Q_{2}\left(N_{2} \times\left(100-M_{2}\right)\right)+Q_{3}\left(N_{3} \times\left(100-M_{3}\right)\right)+\ldots},
$$

where $R$ is C/N ratio of compost mixture, $Q_{n}$ is mass of material $n$ (wet weight basis), $C_{n}$ is carbon (\%) of material $n, N_{n}$ is nitrogen (\%) of material $n$, and $M_{n}$ is moisture content (\%) of material $n$.

By simplifying and rearranging the above equation, the mass of the third material required would be Eq. (3)

$Q_{3}=\frac{R Q_{1} N_{1}\left(100-M_{1}\right)+R Q_{2} N_{2}\left(100-M_{2}\right)-Q_{1} C_{1}\left(100-M_{1}\right)-Q_{2} C_{2}\left(100-M_{2}\right)}{C_{3}\left(100-M_{3}\right)-R N_{3}\left(100-M_{3}\right)}$,

\subsection{Rotary Drum Composter Design}

Fig. 1 shows a schematic diagram of a pilot-scale rotary drum composter of $550 \mathrm{~L}$ capacity operated by batch-mode operation.
The composter is made up of $1.22 \mathrm{~m}$ in length and $0.76 \mathrm{~m}$ in diameter, fabricated by a 4 -mm thick metal sheet. The inner side of the drum is covered with anti-corrosive coating. The drum is mounted on four rubber rollers attached to a metal stand and is rotated manually by its handle. In order to ensure appropriate mixing, agitation and aeration of the wastes during rotation, $40 \times$ $40 \mathrm{~mm}$ angles are welded longitudinally inside the drum. In addition, two adjacent holes of $10 \mathrm{~cm}$ each are made on top of the drum to drain out the excess water. The composting period of 20 days was decided for both proper degradation and stabilization based on the performance of earlier studies regarding in-vessel composting reactors [13]. Manual turning was done after every $24 \mathrm{hr}$ through one complete rotation of the rotary drum to ensure that the material on the top portion moved to the central portion, where it was subjected to higher temperature. Aerobic condition was maintained by opening the top half side doors of the two circular faces.

\subsection{Sampling and Parameter Analysis}

The samples were collected through grab sampling from different locations, mainly from the mid span and end terminals of the pilot-scale rotary drum composter with a compost sampler to minimize disturbance of the adjacent materials. All the grab samples were thoroughly mixed together to make a homogenized sample. Triplicate homogenized samples were collected on 0 day and after $2,4,6,8,10,12,14,16,18$, and 20 days of the composting process and stored at $4^{\circ} \mathrm{C}$ for biological analysis of the wet samples within 2 days. The sub-samples were air dried immediately ground to pass through $0.2 \mathrm{~mm}$ sieve, and stored for physicochemical analysis.

Throughout the composting period, the temperature was monitored every $6 \mathrm{hr}$ using a digital thermometer at three different locations within the pilot-scale rotary drum composter, i.e., at its centre and at its two ends, and the mean of the readings was reported. Each sample was analyzed for the following parameters: $\mathrm{pH}$ and electrical conductivity (EC) (1:10 w/v waste:water extract), ash $\left(550^{\circ} \mathrm{C}\right.$ for $2 \mathrm{hr}$; loss ignition method), total nitrogen using the Kjeldahl method, $\mathrm{NH}_{4}-\mathrm{N}$ and $\mathrm{NO}_{3}-\mathrm{N}$ using $\mathrm{KCl}$ extraction [18], total organic carbon (TOC) content determined according to Mohee et al. [19], available and total phosphorus (acid digestion) using the stannous chloride method [20], potassium, 


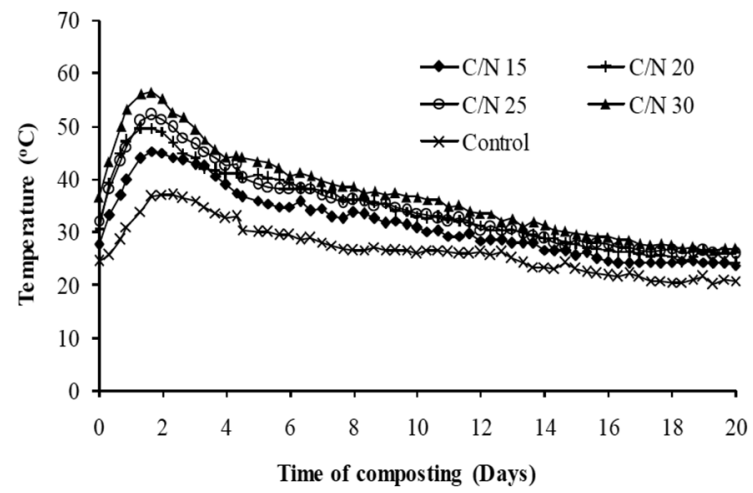

Fig. 2. Temperature pattern during composting over time.

sodium and calcium (acid digest) using flame photometry, and trace elements including $\mathrm{Cr}, \mathrm{Fe}, \mathrm{Cd}, \mathrm{Pb}, \mathrm{Zn}$, and $\mathrm{Cu}$ (acid digest) analyzed using atomic absorption spectroscopy [20]. Biodegradable organic matter was measured as biochemical oxygen demand (BOD) by the dilution method and COD by the dichromate method [20]. Stability of the compost samples was measured either by $\mathrm{CO}_{2}$ evolution or oxygen uptake rates (OUR) [13]. $\mathrm{CO}_{2}$ and OUR test values were used to determine the Solvita maturity index on a scale of 1-8, which represents the maturity level of the compost samples [21].

All the results reported are the means of three replicates. Analysis of variance (ANOVA) and Tukey honestly significant difference (HSD) test were used as a post-hoc analysis to compare the means using STATISTICA software to determine any significant differences among the parameters analyzed for different sets of experiment.

\section{Results and Discussion}

\subsection{Physicochemical Analysis}

The temperature indicates the biological processes taking place during composting and plays a selective role on the evolution and succession of microbiological communities [22]. In the present study, C/N 30, containing an optimum amount of cattle manure and sawdust reached the highest maximum temperature $\left(55.1^{\circ} \mathrm{C}\right)$ on the 2 nd day (Fig. 2), among the temperature regimes of all $\mathrm{C} / \mathrm{N}$ ratios, including control, and entered into the thermophilic phase within a day, indicating quick establishment of microbial activities. The higher rise in temperature at the beginning of composting was attributed to the higher content of easily biodegradable carbon. As the temperature rises above about $40^{\circ} \mathrm{C}$, the mesophilic microorganisms become less competitive and are replaced by others that are thermophilic or heatloving. After the 12th day, when the cooling phase started, the degradation is mainly carried out by actinomycetes and fungus; due to the mineralization of complex organic matter, they degraded at low temperature also. On the other hand, lower peak temperatures were observed in the control experiment followed by C/N 15 and 20 as compared to others, which may be due to the higher amount of sewage sludge, which indicates that sewage sludge without appropriate amendments is less favorable for the growth and biological activity of microorganisms. All of the experiments accomplished ambient temperature at the end of
20 days showing the reflective image of stability.

Moisture loss during the composting process can be viewed as an index of the decomposition rate, since the heat generated during decomposition leads to vaporization [23]. The initial moisture contents were $70.91 \%(\mathrm{C} / \mathrm{N} \mathrm{15}), 68.74 \%(\mathrm{C} / \mathrm{N} \mathrm{20})$, $64.93 \%$ (C/N 25), 62.30\% (C/N 30), and 68.10\% (control); and dropped to $51.01 \%, 48.80 \%, 47.18 \%, 43.23 \%$, and $55.16 \%$ at the end of 20 days of composting period (Table 2). The highest moisture loss occurred in $\mathrm{C} / \mathrm{N} 30(30.61 \%)$ and it correlated with the higher temperature regime of $\mathrm{C} / \mathrm{N} 30$. Leachate formation was not observed during the composting period. On analyzing the results by ANOVA, the decrease in moisture content varied significantly between the days $(p<0.05)$.

Table 2 displays that the $\mathrm{pH}$ value increased during the initial stage of composting probably due to the activity of proteolytic bacteria, which may release ammonia, when organic matter is to be decomposed. On the other hand, the initial $\mathrm{pH}$ vales were decreased in $\mathrm{C} / \mathrm{N}$ ratio 20,30 , and the control experiments within 6 days, but later reached the neutral condition at the end of 20 days. The reduction in $\mathrm{pH}$ may be due to $\mathrm{CO}_{2}$ and organic acids being produced during microbial metabolism [24]. As the composting proceeds, the organic acids become neutralized and compost material tends toward a neutral $\mathrm{pH}$ [25]. Similar observations were found in all $\mathrm{C} / \mathrm{N}$ ratios as the $\mathrm{pH}$ reduced during the initial 6 days, and further increased gradually up to 8. Significant differences in $\mathrm{pH}$ were observed between all the experiments $(p<0.05)$.

The EC value reflected the degree of salinity in the compost indicating its possible phytotoxic/phyto-inhibitory effects on the growth of plant, if applied to soil [26]. In this study, a gradual increase in EC was observed with time in all the experiments (Table 2). However, the higher final EC values shown in C/N 15, 20 , and control experiments may be due to the larger availability of sewage sludge as compared to C/N 25 and 30; which are not suited for agricultural purposes. The increase in EC might have been due to the loss of weight of organic matter and release of different mineral salts in available forms (such as phosphate, ammonium, potassium) as reported by Garg et al. [27]. For the improvement of agricultural soils, the acceptable level of EC required in compost should be lower than $4 \mathrm{dS} / \mathrm{m}$ [28]. On analyzing the results by ANOVA, the EC varied significantly between the $\mathrm{C} / \mathrm{N}$ ratios including control $(p<0.05)$.

The change in the TOC content during the composting period is detailed in Table 2 . The organic matter becomes mineralized as the composting proceeds caused by the degradation of easily degradable compounds, such as proteins, cellulose, and hemi-cellulose, which are utilized by microorganisms as $\mathrm{C}$ and $\mathrm{N}$ sources. During organic matter degradation, microbes utilize $60 \%$ to $70 \%$ of the carbon as $\mathrm{CO}_{2}$ and immobilize only $30 \%$ to $40 \%$ of the carbon into their body as cellular components [12]. Hence, the TOC content is useful for evaluating the age and physical properties of the compost. In this study, the amount of TOC were $26.83 \%, 27.51 \%, 28.53 \%, 29.72 \%$, and $23.61 \%$ initially, and reduced up to $17.76 \%, 17.78 \%, 17.95 \%, 17.84 \%$, and $17.56 \%$ in $\mathrm{C} / \mathrm{N} 15,20,25,30$, and control, respectively. Results indicated that higher carbon degradation occurred in C/N 30 (39.97\%) followed by C/N 25 (37.08\%), C/N 20 (35.36\%), C/N 15 (33.81\%), and control $(25.62 \%)$, respectively, which correlated with the higher temperature profile of C/N 30. Significant variations in TOC were observed between the $\mathrm{C} / \mathrm{N}$ ratios including control $(p<0.05)$.

Table 3 shows the time course of the total nitrogen consist- 


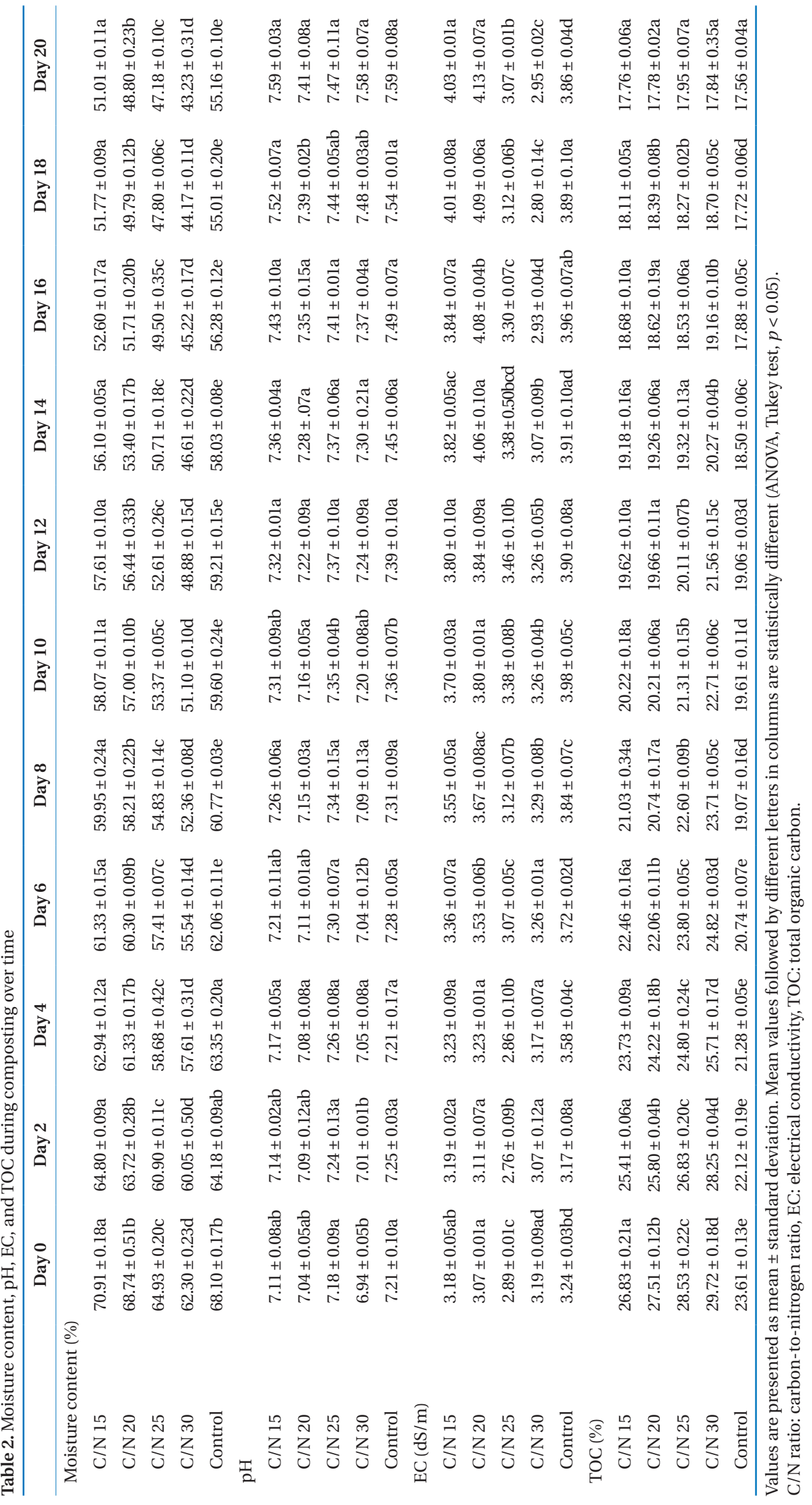


ing of the inorganic forms of nitrogen $\left(\mathrm{NH}_{4}-\mathrm{N}\right.$ and $\left.\mathrm{NO}_{3}-\mathrm{N}\right)$. While the nitrogen content in sludge was higher as compared to others (Table 1), as a result, the nitrogen content was much higher in $\mathrm{C} / \mathrm{N} 15$ and control as compared to others, due to the availability of a large amount of sewage sludge. The total nitrogen contents in all experiments (especially in $\mathrm{C} / \mathrm{N} 30$ ) increased at the end of the composting period (Table 3), due to the net loss of dry mass in terms of carbon dioxide, as well as the water loss by evaporation caused by heat evolved during oxidization of organic matter [26]. Also, Kalamdhad and Kazmi [12] suggested that nitrogen fixing bacteria might have contributed to the increase in total nitrogen in the later stage of composting.

The changes in concentration of $\mathrm{NH}_{4}-\mathrm{N}$ and $\mathrm{NO}_{3}-\mathrm{N}$ in all experiments followed a similar trend during drum composting. As the composting proceeds, $\mathrm{NH}_{4}-\mathrm{N}$ concentration decreased from $0.79 \%-1.10 \%$ to $0.04 \%-0.21 \%$ in all $\mathrm{C} / \mathrm{N}$ ratios including control (Table 3). Higher initial $\mathrm{NH}_{4}-\mathrm{N}$ concentration could be due to the conversion of organic nitrogen to $\mathrm{NH}_{4}-\mathrm{N}$, through volatilization and immobilization by microorganisms [26]. It has been noted that the absence or decrease in $\mathrm{NH}_{4}-\mathrm{N}$ is an indicator of quality compost. $\mathrm{NH}_{4}-\mathrm{N}$ concentration of $0.04 \%$ is recommended as the maximum content in matured compost [29]. Here, C/N 30 possessed the quality compost as compared to the others.

Nitrate was almost absent in the cattle manure and sawdust, but higher concentration was observed in sewage sludge, so all the experiments found an initial nitrate concentration (Table 3). Nitrification occurred only when the temperature of the material was below $40^{\circ} \mathrm{C}$, as the intensity of the process was dependent on the quantity of $\mathrm{NH}_{4}-\mathrm{N}$ available to the nitrifying bacteria. The concentration of $\mathrm{NO}_{3}-\mathrm{N}$ was almost nil during the first four days due to inhibition by an excessive amount of ammonia. The high temperature and excessive amount of ammonia inhibited the activity and the growth of nitrifying bacteria in the thermophilic phase [30]. This suggests that organic nitrogen mineralization is the limiting step in nitrification, since such mineralization was extremely low during the last phase of composting, when the supply of ammonium available to the nitrifying bacteria would have been reduced [31]. Hence, the concentration of nitrates was increased slightly in the later phase of composting. Significant differences in total nitrogen, $\mathrm{NH}_{4}-\mathrm{N}$ and $\mathrm{NO}_{3}-\mathrm{N}$ were observed between all the experiments $(p<0.05)$.

Phosphorous content gradually increased during the composting due to the net loss of dry mass, and losses of organic carbon, hydrogen, nitrogen and oxygen from the reactor as $\mathrm{CO}_{2}, \mathrm{H}_{2} \mathrm{~S}$ and $\mathrm{H}_{2} \mathrm{O}$ during composting. The water solubility of phosphorous decreased with the humification, thereby showing that phosphorous solubilized during the decomposition was subjected to further immobilization by the compost accelerator microorganisms. The change of total and available phosphorus showed a gradual increase throughout the composting period (Table 4). The final total phosphorus of C/N $30(4.43 \%)$ was higher than C/N 15 (3.23\%), C/N 20 (3.52\%), C/N 25 (4.03\%), and control (4.27\%) respectively, indicating higher microbial activities, resulting in more mineralization. Similar observations were found for available phosphorus. On analyzing the results by ANOVA, the total and available phosphorus varied significantly between the experiments $(p<0.05)$.

Table 4 shows the concentration of macronutrients; namely, total $\mathrm{Na}, \mathrm{K}, \mathrm{Ca}$ and $\mathrm{Fe}$ in all the experiments, throughout the composting process. These nutrients are needed for microbial metabolism, and their availability in final compost is an indication of good quality fertilizers for plant. In this study, all the macronutrients (K, Na, $\mathrm{Ca}$ and $\mathrm{Fe}$ ) are gradually increased till the end of the composting, due to the net loss of dry mass [2]. On analyzing the result by ANOVA, significant differences in macronutrients were observed, between all the experiments $(p<0.05)$.

The total concentrations of regulated trace elements $(\mathrm{Ni}, \mathrm{Cd}$, $\mathrm{Cu}, \mathrm{Zn}, \mathrm{Mn}, \mathrm{Cr}$, and $\mathrm{Pb}$ ) during composting are shown in Table 5. Heavy metals emerge into sewage sludge from various sources like batteries, consumer electronics, ceramics, light bulbs, plastics, house dust, and paint chips, etc.; thus, the compost made from sewage sludge may have heavy metal concentrations. Most of the trace elements are actually needed by plants for normal growth although in limited quantities. However, in higher concentrations, they are likely to have detrimental effects upon plant growth. So, prior to compost application to the soils, there is a need to determine the trace element concentrations in the final composts, which provide the fertilizer requirements of plant. The increase of total metal content was due to weight loss in the course of composting following organic matter decomposition, release of $\mathrm{CO}_{2}$, and mineralization processes [32]. The total concentrations in the final compost were very low and it is considered as soil fertilizer of good quality according to the standards to ensure safe application of compost that are laid down in the $\mathrm{Mu}-$ nicipal Waste (Management \& Handling rules) as notified by the Ministry of Environment and Forest, Government of India [33] and the Canadian Council of Ministers of the Environment [34]. Significant differences in trace elements were observed between all the experiments $(p<0.05)$.

\subsection{Stability and Biological Analysis}

In the present study, a gradual decrease in $\mathrm{C} / \mathrm{N}$ ratio was observed in all the experiments during 20 days of composting period; and they finally reached constant values indicating the stabilization of the compost (Table 3). The changes in $\mathrm{C} / \mathrm{N}$ ratio during composting reflect the organic matter decomposition and stabilization achieved. The decomposition of organic matter is brought about by living organisms, which utilize the carbon as a source of energy and nitrogen for building cell structures [5]. Higher reduction in $\mathrm{C} / \mathrm{N}$ ratio was observed in $\mathrm{C} / \mathrm{N} 30$ (60.5\%) followed by C/N 20 (54.3\%), C/N 25 (53.71\%), C/N 15 (46.64\%), and control (39.26\%), which indicate the high degree of organic matter stabilization achieved. If the $\mathrm{C} / \mathrm{N}$ ratio of compost is more, the excess carbon tends to utilize nitrogen in the soil to build cell protoplasm. This results in loss of nitrogen of the soil and is known as the robbing of nitrogen in the soil. On the other hand, if the $\mathrm{C} / \mathrm{N}$ ratio is too low, the resultant product does not help improve the structure of the soil. Hence, it is desirable to control the process, so that the final $\mathrm{C} / \mathrm{N}$ ratio is less than or equal to 20 [33]. On analyzing the result by ANOVA, significant differences were observed between all the experiments $(p<0.05)$.

$\mathrm{CO}_{2}$ evolution is the most direct technique to evaluate compost stability, because it measures carbon directly derived from the compost being tested, caused by mineralization of the compost's organic matter. Thus, $\mathrm{CO}_{2}$ evolution correlated with the microbial respiration and aerobic biological activity [13]. Here, the $\mathrm{CO}_{2}$ evolution rates reduced by $94.65 \%, 85.94 \%, 85.64 \%$, $78.67 \%$, and $65.68 \%$ after 20 days in C/N 30, 20, 25, 15, and control, respectively (Fig. 3). Results suggested the greater reduction in $\mathrm{CO}_{2}$ evolution values in $\mathrm{C} / \mathrm{N} 30$ as compared to the others indicated more stabilization in $\mathrm{C} / \mathrm{N}$ 30. In addition, the higher $\mathrm{CO}_{2}$ evolution value at the beginning indicates the elevated microbial respiration of the readily available carbon in the composting 


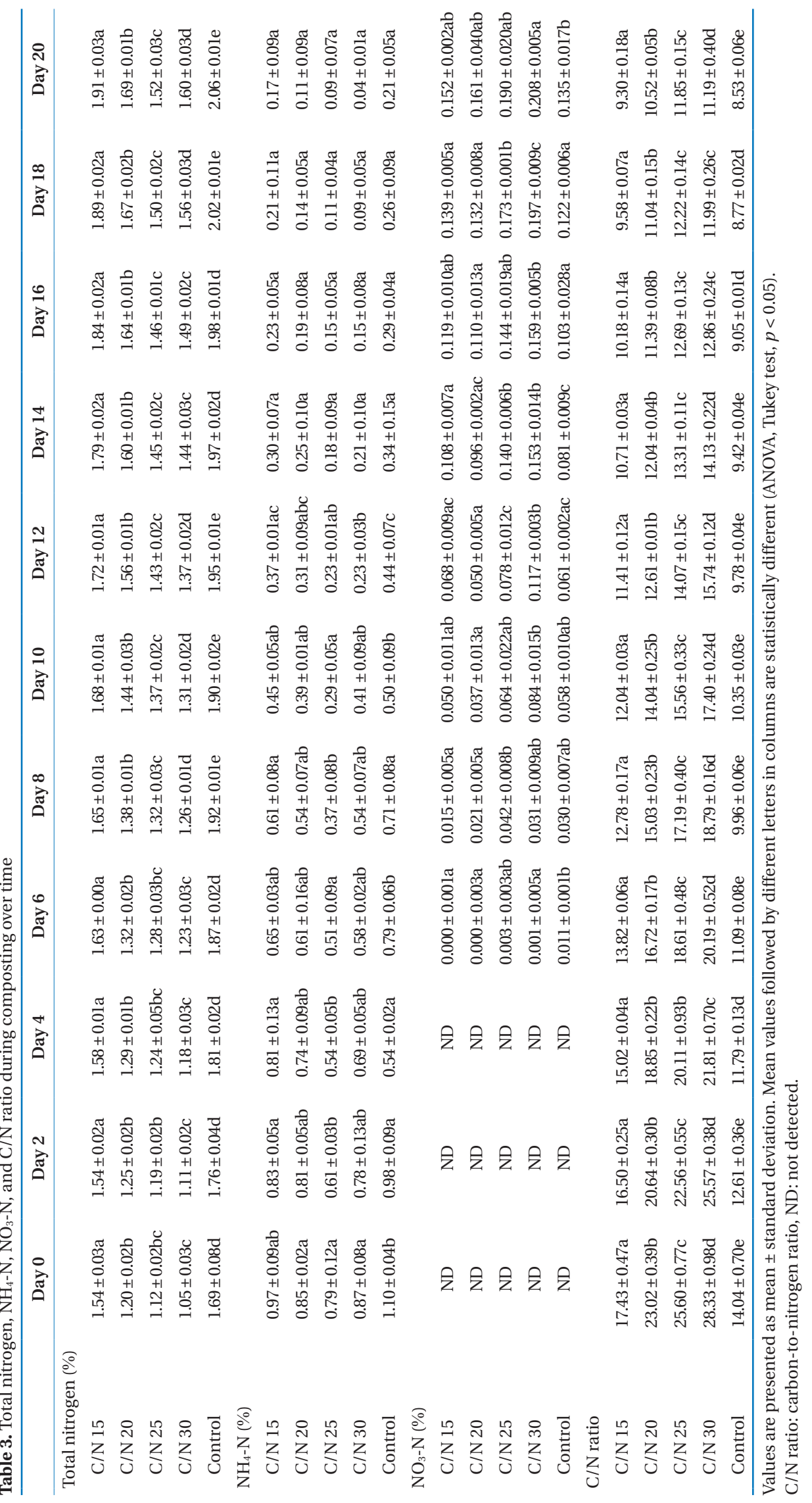




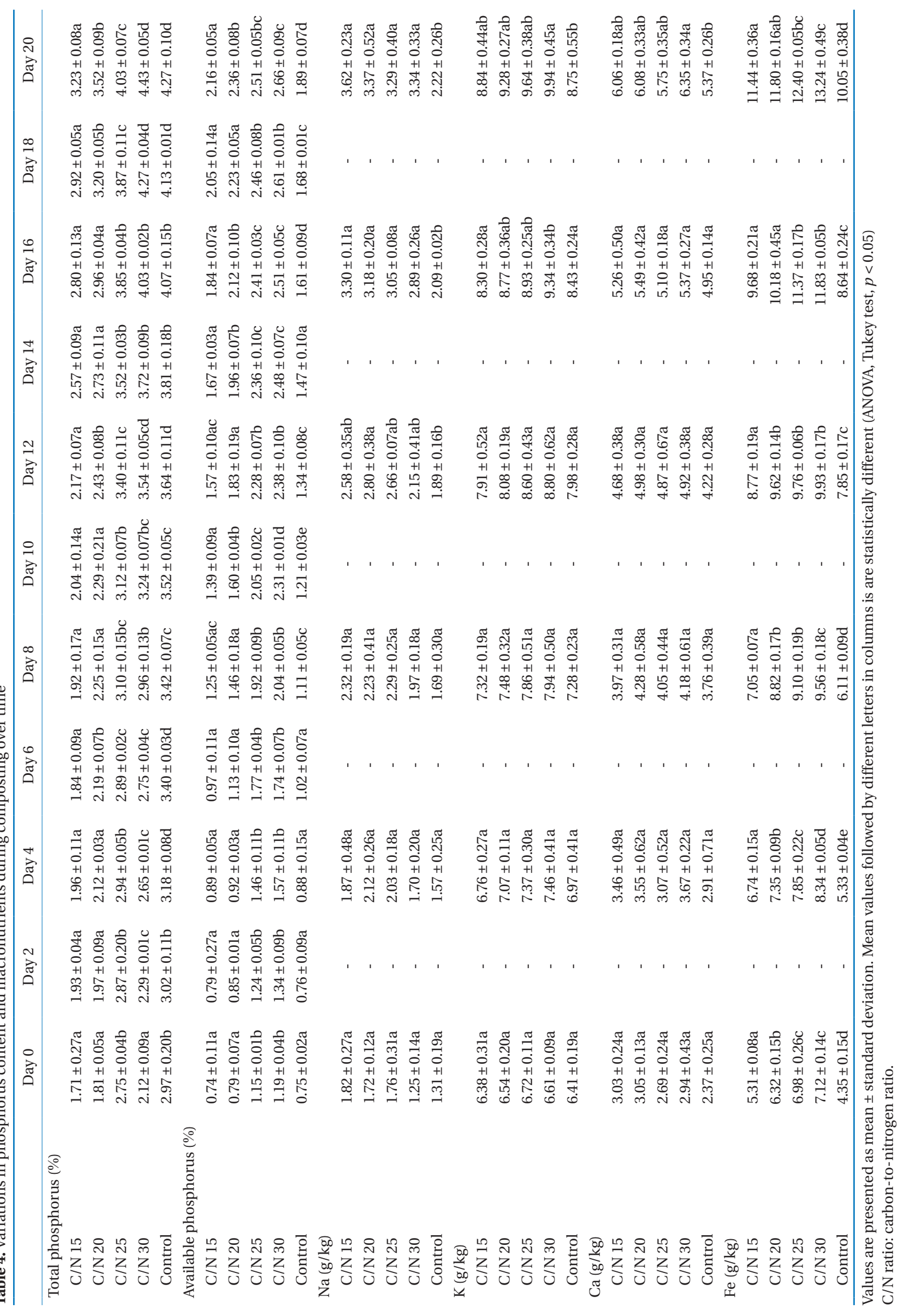


mixture. The decrease in the $\mathrm{CO}_{2}$ evolution rate during composting results from the reduction in metabolic activities. The lower final values of $\mathrm{CO}_{2}$ evolution strongly recommended that sewage sludge coupled with cattle manure and sawdust could produce stable and quality compost without any limitations using drum composting. The $\mathrm{CO}_{2}$ evolution varied significantly for all the reactors $(p<0.05)$. In addition, Solvita results based on $\mathrm{CO}_{2}$ evolution increased from 3 to 8 for all the experiments (especially in $\mathrm{C} / \mathrm{N}$ 30) indicating that the composts entered into a good stable condition after 20 days.

The OUR evaluates the amount of readily biodegradable organic matter still present in the sample, through its carbonaceous oxygen demand. Thus, it is important to measure the respiration rate for determination of biological activities in the compost [13]. In all the reactors, the sharp reduction in OUR values that was observed correlates with a temperature decline, and lesser availability of organic matter as the composting progressed. A greater decrease in OUR value was shown in the $\mathrm{C} / \mathrm{N}$ ratio $30(94.97 \%)$, followed by $\mathrm{C} / \mathrm{N}$ ratio 25 (86.51\%), C/N 15 (80.18\%), C/N 20 (78.93\%), and control (75.42\%), respectively (Fig. 3). In the initial stage, higher respiration rates were observed for all the experiments (especially C/N 30), due to the high availability of readily degradable cattle manure mixed with the sewage sludge and sawdust. As composting proceeds, larger organic molecules are broken down to smaller, soluble ones, and temporarily more substrate may become available. In this study, the OUR values dropped progressively after the initial reduction in all cases; while the decline is moderate at the later stage indicating stable and quality compost. On analyzing the results by ANOVA, the OUR varied significantly between the reactors $(p<$

Table 5. Variations in trace elements $(\mathrm{Pb}, \mathrm{Cd}, \mathrm{Cu}, \mathrm{Zn}, \mathrm{Mn}$, and $\mathrm{Cr})$ during composting over time

\begin{tabular}{|c|c|c|c|c|c|c|}
\hline & Day 0 & Day 4 & Day 8 & Day 12 & Day 16 & Day 20 \\
\hline \multicolumn{7}{|c|}{$\mathrm{Pb}$ (mg/kg) } \\
\hline C/N 15 & $198.5 \pm 8.3 \mathrm{a}$ & $248.3 \pm 4.5 \mathrm{a}$ & $275.0 \pm 3.0 \mathrm{a}$ & $307.5 \pm 5.3 \mathrm{a}$ & $352.3 \pm 2.5 \mathrm{a}$ & $399.5 \pm 6.8 \mathrm{a}$ \\
\hline $\mathrm{C} / \mathrm{N} 20$ & $259.3 \pm 3.5 b$ & $296.0 \pm 2.8 b$ & $329.8 \pm 3.8 b$ & $368.3 \pm 4.5 b$ & $405.3 \pm 5.8 \mathrm{~b}$ & $450.5 \pm 7.3 b$ \\
\hline $\mathrm{C} / \mathrm{N} 25$ & $297.3 \pm 1.8 c$ & $300.0 \pm 3.5 b$ & $357.5 \pm 2.3 c$ & $396.8 \pm 2.5 c$ & $413.3 \pm 6.0 \mathrm{~b}$ & $440.0 \pm 5.5 b$ \\
\hline C/N 30 & $274.5 \pm 2.8 \mathrm{~d}$ & $283.5 \pm 3.0 \mathrm{c}$ & $321.3 \pm 5.3 b$ & $343.8 \pm 4.8 \mathrm{~d}$ & $357.5 \pm 8.5 \mathrm{a}$ & $416.0 \pm 3.8 \mathrm{a}$ \\
\hline Control & $203.8 \pm 3.5 a$ & $202.3 \pm 4.8 \mathrm{~d}$ & $234.5 \pm 9.5 d$ & $245.6 \pm 10.3 \mathrm{e}$ & $277.8 \pm 7.5 c$ & $300.0 \pm 8.3 c$ \\
\hline \multicolumn{7}{|c|}{$\mathrm{Cd}(\mathrm{mg} / \mathrm{kg})$} \\
\hline $\mathrm{C} / \mathrm{N} 15$ & $34.3 \pm 1.8 \mathrm{a}$ & $39.5 \pm 1.3 \mathrm{a}$ & $41.5 \pm 0.5 \mathrm{a}$ & $47.3 \pm 2.8 \mathrm{a}$ & $53.0 \pm 1.3 \mathrm{ac}$ & $56.3 \pm 3.5 \mathrm{a}$ \\
\hline $\mathrm{C} / \mathrm{N} 20$ & $49.5 \pm 1.8 b$ & $49.8 \pm 2.5 b$ & $53.8 \pm 1.8 b$ & $56.3 \pm 3.5 b$ & $60.8 \pm 1.3 b$ & $65.3 \pm 1.8 \mathrm{~b}$ \\
\hline C/N 25 & $42.5 \pm 1.0 \mathrm{c}$ & $49.0 \pm 2.8 b$ & $52.8 \pm 0.5 b$ & $57.3 \pm 1.3 \mathrm{~b}$ & $60.0 \pm 2.8 b$ & $66.5 \pm 3.3 b$ \\
\hline C/N 30 & $45.8 \pm 0.5 c$ & $49.5 \pm 1.8 b$ & $51.3 \pm 3.5 b$ & $53.8 \pm 1.8 b$ & $57.5 \pm 1.5 \mathrm{ab}$ & $64.3 \pm 2.0 \mathrm{~b}$ \\
\hline Control & $31.0 \pm 1.3 \mathrm{a}$ & $33.5 \pm 0.8 c$ & $36.8 \pm 1.5 \mathrm{a}$ & $40.5 \pm 1.0 \mathrm{c}$ & $49.4 \pm 2.8 \mathrm{c}$ & $53.3 \pm 1.3 \mathrm{a}$ \\
\hline \multicolumn{7}{|c|}{$\mathrm{Cu}(\mathrm{mg} / \mathrm{kg})$} \\
\hline C/N 15 & $197.3 \pm 2.3 \mathrm{a}$ & $215.3 \pm 1.8 \mathrm{a}$ & $218.5 \pm 1.5 \mathrm{a}$ & $229.0 \pm 3.0 \mathrm{a}$ & $236.8 \pm 2.5 a$ & $246.8 \pm 1.8 \mathrm{a}$ \\
\hline $\mathrm{C} / \mathrm{N} 20$ & $193.5 \pm 4.8 \mathrm{a}$ & $213.0 \pm 3.8 \mathrm{a}$ & $221.3 \pm 3.5 a$ & $236.5 \pm 2.0 \mathrm{~b}$ & $247.8 \pm 1.8 \mathrm{~b}$ & $262.5 \pm 3.0 \mathrm{~b}$ \\
\hline $\mathrm{C} / \mathrm{N} 25$ & $168.8 \pm 2.5 b$ & $187.3 \pm 3.3 b$ & $199.0 \pm 2.5 b$ & $217.5 \pm 0.8 \mathrm{c}$ & $224.5 \pm 1.8 \mathrm{c}$ & $241.8 \pm 3.5 \mathrm{a}$ \\
\hline $\mathrm{C} / \mathrm{N} 30$ & $159.0 \pm 1.5 c$ & $167.8 \pm 5.5 \mathrm{c}$ & $178.0 \pm 0.8 c$ & $191.8 \pm 2.5 \mathrm{~d}$ & $208.8 \pm 3.3 d$ & $213.3 \pm 1.8 \mathrm{c}$ \\
\hline Control & $150.0 \pm 2.5 d$ & $158.3 \pm 3.8 c$ & $171.5 \pm 1.8 \mathrm{~d}$ & $172.8 \pm 3.5 \mathrm{e}$ & $181.8 \pm 1.8 \mathrm{e}$ & $181.3 \pm 3.0 \mathrm{~d}$ \\
\hline \multicolumn{7}{|c|}{$\mathrm{Zn}(\mathrm{mg} / \mathrm{kg})$} \\
\hline C/N 15 & $993.5 \pm 4.5 \mathrm{a}$ & $1,052.0 \pm 6.0 \mathrm{a}$ & $1,199.8 \pm 5.5 \mathrm{a}$ & $1,273.8 \pm 4.8 \mathrm{a}$ & $1,357.3 \pm 6.3 \mathrm{a}$ & $1,339.3 \pm 3.5 \mathrm{a}$ \\
\hline $\mathrm{C} / \mathrm{N} 20$ & $856.5 \pm 2.5 b$ & $934.8 \pm 3.3 \mathrm{~b}$ & $1,040.8 \pm 4.8 b$ & $1,172.3 \pm 5.3 b$ & $1,231.3 \pm 4.8 \mathrm{~b}$ & $1,284.5 \pm 3.8 b$ \\
\hline $\mathrm{C} / \mathrm{N} 25$ & $845.3 \pm 2.3 c$ & $877.5 \pm 3.0 \mathrm{c}$ & $940.0 \pm 1.8 \mathrm{c}$ & $951.8 \pm 7.5 \mathrm{c}$ & $1,052.0 \pm 5.0 \mathrm{c}$ & $1,161.8 \pm 4.8 \mathrm{c}$ \\
\hline C/N 30 & $719.8 \pm 1.0 \mathrm{~d}$ & $766.8 \pm 2.8 \mathrm{~d}$ & $822.3 \pm 5.3 \mathrm{~d}$ & $892.3 \pm 1.8 \mathrm{~d}$ & $976.0 \pm 2.5 \mathrm{~d}$ & $1,018.8 \pm 3.3 \mathrm{~d}$ \\
\hline Control & $1,077.3 \pm 5.0 \mathrm{e}$ & $1,082.8 \pm 3.8 \mathrm{e}$ & $1,166.0 \pm 2.5 \mathrm{e}$ & $1,278.8 \pm 3.3 a$ & $1,337.5 \pm 1.8 \mathrm{e}$ & $1,382.3 \pm 3.5 \mathrm{e}$ \\
\hline \multicolumn{7}{|c|}{ Mn (mg/kg) } \\
\hline C/N 15 & $480.0 \pm 5.5 a$ & $487.5 \pm 8.5 a$ & $555.0 \pm 2.5 a$ & $615.5 \pm 3.0 \mathrm{a}$ & $654.5 \pm 4.5 \mathrm{a}$ & $707.5 \pm 5.5 a$ \\
\hline $\mathrm{C} / \mathrm{N} 20$ & $502.5 \pm 9.5 b$ & $504.0 \pm 5.0 \mathrm{~b}$ & $525.5 \pm 6.5 b$ & $578.0 \pm 4.5 b$ & $625.5 \pm 3.0 \mathrm{~b}$ & $660.0 \pm 6.5 b$ \\
\hline C/N 25 & $390.0 \pm 1.5 c$ & $395.5 \pm 4.0 \mathrm{c}$ & $443.0 \pm 3.5 c$ & $480.5 \pm 4.0 \mathrm{c}$ & $570.5 \pm 8.0 \mathrm{c}$ & $600.0 \pm 6.5 c$ \\
\hline C/N 30 & $337.5 \pm 6.0 \mathrm{~d}$ & $345.0 \pm 3.5 \mathrm{~d}$ & $398.5 \pm 2.5 d$ & $416.5 \pm 3.0 \mathrm{~d}$ & $487.0 \pm 8.0 \mathrm{~d}$ & $538.5 \pm 4.0 \mathrm{~d}$ \\
\hline Control & $275.0 \pm 2.5 \mathrm{e}$ & $321.5 \pm 3.5 \mathrm{e}$ & $361.5 \pm 1.0 \mathrm{e}$ & $368.5 \pm 10.5 \mathrm{e}$ & $398.0 \pm 4.0 \mathrm{e}$ & $398.5 \pm 8.5 \mathrm{e}$ \\
\hline \multicolumn{7}{|l|}{$\mathrm{Cr}(\mathrm{mg} / \mathrm{kg})$} \\
\hline C/N 15 & $165.8 \pm 3.8 \mathrm{a}$ & $186.8 \pm 5.5 a$ & $198.5 \pm 2.8 \mathrm{a}$ & $210.0 \pm 3.0 \mathrm{a}$ & $233.3 \pm 4.3 \mathrm{a}$ & $245.3 \pm 1.8 \mathrm{a}$ \\
\hline $\mathrm{C} / \mathrm{N} 20$ & $177.0 \pm 1.3 \mathrm{~b}$ & $193.5 \pm 5.0 \mathrm{a}$ & $202.5 \pm 1.8 \mathrm{a}$ & $206.8 \pm 4.0 \mathrm{ac}$ & $218.3 \pm 3.0 \mathrm{~b}$ & $238.5 \pm 1.0 \mathrm{a}$ \\
\hline $\mathrm{C} / \mathrm{N} 25$ & $155.3 \pm 3.8 \mathrm{c}$ & $167.8 \pm 4.8 \mathrm{bc}$ & $178.5 \pm 1.8 \mathrm{bc}$ & $190.5 \pm 6.5 \mathrm{bd}$ & $194.8 \pm 2.3 c$ & $208.3 \pm 3.8 b$ \\
\hline $\mathrm{C} / \mathrm{N} 30$ & $162.5 \pm 3.8 \mathrm{ac}$ & $174.8 \pm 2.5 b$ & $186.8 \pm 4.8 b$ & $197.3 \pm 3.3 \mathrm{~cd}$ & $206.0 \pm 4.5 \mathrm{~d}$ & $216.5 \pm 2.5 c$ \\
\hline Control & $137.5 \pm 3.0 \mathrm{~d}$ & $160.3 \pm 1.3 \mathrm{c}$ & $169.3 \pm 5.3 c$ & $175.0 \pm 2.5 \mathrm{e}$ & $180.5 \pm 2.8 \mathrm{e}$ & $192.75 \pm 4.5 \mathrm{~d}$ \\
\hline
\end{tabular}

Values are presented as mean \pm standard deviation. Mean values followed by different letters in columns are statistically different (ANOVA, Tukey test, $p<0.05$ )

$\mathrm{C} / \mathrm{N}$ ratio: carbon-to-nitrogen ratio. 

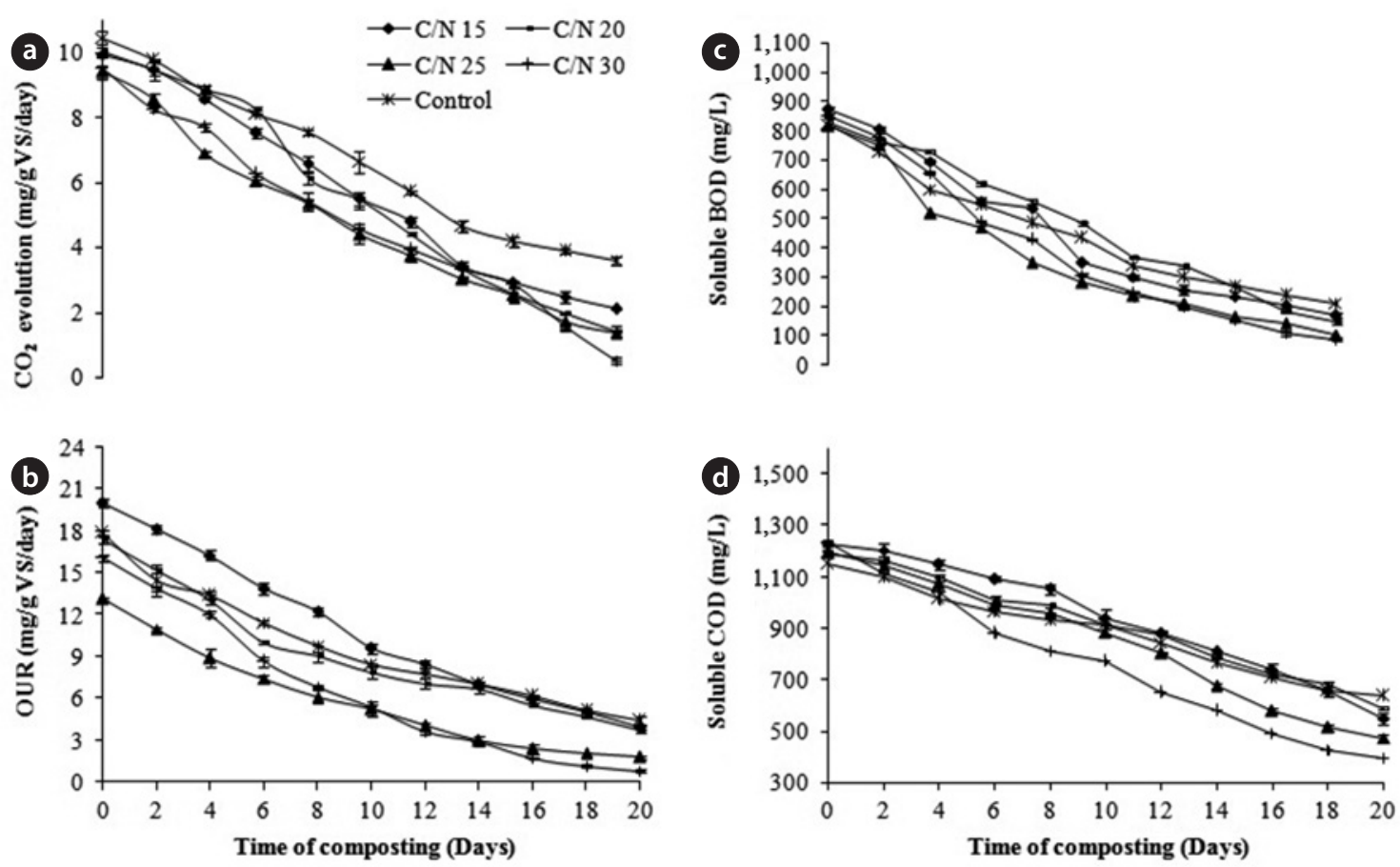

Fig. 3. Variation in (a) $\mathrm{CO}_{2}$ evolution, (b) oxygen uptake rate (OUR), (c) soluble biochemical oxygen demand (BOD) and (d) chemical oxygen demand (COD) during composting over time.

0.05). The Solvita maturation index based on the OUR increased from 5 to 8 in C/N 25 and 30, whereas the OUR increased from 4 to 7 in the $\mathrm{C} / \mathrm{N} 15,20$, and control experiments.

The composting process proceeds until all biodegradable organic material is stabilized at which stage it is odorless and pathogen free, and a poor breeding substrate for the breeding of flies and other insects. Thus, the percentage of readily biodegradable organic matter is an important aspect of compost quality. Even if the compost is stable, care should be taken while applying to soil for crop use, because the biological processes will continue and can strip the nutrients of soil [2]. In all the experiments, BOD and COD were reduced (Fig. 3). The reduction of BOD for all the reactors were of the range $74 \%-90 \%$; whereas, those of COD were in the range $45 \%-68 \%$. The maximum reductions in BOD and COD were observed in C/N 30, indicating more degradation of organic matter at the end of the composting period. Significant differences were observed in the values of BOD and COD for all the experiments $(p<0.05)$.

\section{Conclusions}

The compost made during the $\mathrm{C} / \mathrm{N} 30$ experiment possessed higher temperature compared to others, due to the optimized nutrient balance, which provides feasible conditions for microbial and biological activities. The lower final EC, $\mathrm{NH}_{4}-\mathrm{N}$ and higher final phosphorus in $\mathrm{C} / \mathrm{N} 30$ concluded the optimal waste combination of sewage sludge, cattle manure, and sawdust. The higher loss of organic carbon in $\mathrm{C} / \mathrm{N} 30$ justified the obtained results. The higher final concentration of nutrients and limited trace element content ensured the quality of compost prepared from sewage sludge in combination with cattle manure and sawdust. Hence, the present study concluded that the optimal deg- radation of sewage sludge is possible in the presence of carbonaceous material, i.e., cattle manure and sawdust.

\section{References}

1. Ahlberg G, Gustafsson O, Wedel P. Leaching of metals from sewage sludge during one year and their relationship to particle size. Environ. Pollut. 2006;144:545-553.

2. Khwairakpam M, Bhargava R. Vermitechnology for sewage sludge recycling. J. Hazard. Mater. 2009;161:948-954.

3. Tuomela M, Vikman M, Hatakka A, Itavaara M. Biodegradation of lignin in a compost environment: a review. Bioresour. Technol. 2000;72:169-183.

4. Finstein MS. Composting in the context of municipal solid waste management. In: Mitchell R, ed. Environmental microbiology. New York: John Wiley \& Sons; 1992. p. 355-374.

5. Kalamdhad AS, Kazmi AA. Effects of C/N ratio on mixed organic waste composting in a rotary drum composter. Int. J. Environ. Eng. 2009;1:187-207.

6. Paredes C, Roig A, Bernal MP, Sanchez-Monedero MA, Cegarra J. Evolution of organic matter and nitrogen during co-composting of olive mill wastewater with solid organic wastes. Biol. Fertil. Soils 2000;32:222-227.

7. Eftoda G, McCartney D. Determining the critical bulking agent requirement for municipal biosolids composting. Compost Sci. Util. 2004;12:208-218.

8. Tang JC, Inoue Y, Yasuta T, Yoshida S, Katayama A. Chemical and microbial properties of various compost products. Soil Sci. Plant Nutr. 2003;49:273-280.

9. Vuorinen AH, Saharinen MH. Evolution of microbiological and chemical parameters during manure and straw co-composting in a drum composting system. Agric. Ecosyst. Envi- 
ron. 1997;66:19-29.

10. Mohee R, Mudhoo A. Analysis of the physical properties of an in-vessel composting matrix. J. Powder Technol. 2005;155:9299.

11. Aboulam S, Morvan B, Revel JC. Use of a rotating-drum pilot plant to model the composting of household waste on an industrial scale. Compost Sci. Util. 2006;14:184-190.

12. Kalamdhad AS, Kazmi AA. Mixed organic waste composting using rotary drum composter. Int. J. Environ. Waste Manag. 2008;2:24-36.

13. Kalamdhad AS, Pasha M, Kazmi AA. Stability evaluation of compost by respiration techniques in a rotary drum composter. Resour. Conserv. Recycl. 2008;52:829-834.

14. Lasaridi KE, Stentiford EI. A simple respirometric technique for assessing compost stability. Water Res. 1998;32:37173723.

15. Federal Compost Quality Assurance Organization. Methods book for the analysis of compost-in addition with the results of the parallel interlaboratory test 1993. Stuttgart: Federal Compost Quality Assurance Organization ; 1994.

16. Tyler M, Diddy S, Germain JS, Lombard S, Nightingale D. Interim guidelines for compost quality. Olympia: Washington State Department of Ecology; 1994.

17. Cornell Waste Management Institute. Calculate $\mathrm{C} / \mathrm{N}$ ratio for three materials [Internet]. Ithaca: Cornell University; c1996 [cited 2014 Jan 15]. Available from: http://compost.css.cornell.edu/calc/2.html.

18. Tiquia SM, Tam NF. Fate of nitrogen during composting of chicken litter. Environ. Pollut. 2000;110:535-41.

19. Mohee R, Driver MF, Sobratee N. Transformation of spent broiler litter from exogenous matter to compost in a subtropical context. Bioresour. Technol. 2008;99:128-36.

20. Clesceri LS, Greenberg AE, Trussell RR. Standard methods for the examination of water and wastewater. 17th ed. Washington: American Public Health Association; 1989.

21. Cabanas-Vargas DD, Sanchez-Monedero MA, Urpilainen ST, Kamilaki A, Stentiforg EI. Assessing the stability and maturity of compost at large-scale plants. Ingenieria 2005;9:25-30.

22. Hassen A, Belguith K, Jedidi N, Cherif A, Cherif M, Boudabous A. Microbial characterization during composting of municipal solid waste. Bioresour. Technol. 2001;80:217-225.

23. Liao PH, Jones L, Lau AK, Walkemeyer S, Egan B, Holbek N. Composting of fish wastes in a full-scale in-vessel system. Bioresour. Technol. 1996;59:163-168.

24. Haimi J, Hutha V. Capacity of various organic residues to support adequate earthworm biomass in vermicomposting. Biol. Fertil. Soils 1986;2:23-27.

25. Ko HJ, Kim KY, Kim HT, Kim CN, Umeda M. Evaluation of maturity parameters and heavy metal contents in composts made from animal manure. Waste Manag. 2008;28:813-820.

26. Huang GF, Wong JW, Wu QT, Nagar BB. Effect of $\mathrm{C} / \mathrm{N}$ on composting of pig manure with sawdust. Waste Manag. 2004;24:805-813.

27. Garg P, Gupta A, Satya S. Vermicomposting of different types of waste using Eisenia foetida: a comparative study. Bioresour. Technol. 2006;97:391-395.

28. Rao Bhamidimarri SM, Pandey SP. Aerobic thermophilic composting of piggery solid wastes. Water Sci. Technol. 1996;33:89-94.

29. Zucconi F, Monaco A, Forte M, de Bertoldi M. Phytotoxins during the stabilization of organic matter. In: Gasser JK, ed. Composting of agricultural and other wastes. London: Elsevier Applied Science; 1985. p. 73-86.

30. Morisaki N, Phae CG, Nakasaki K, Shoda M, Kubota H. Nitrogen transformation during thermophilic composting. $J$. Ferment. Bioeng. 1989;67:57-61.

31. Sanchez-Monedero MA, Roig A, Paredes C, Bernal MP. Nitrogen transformation during organic waste composting by the Rutgers system and its effects on $\mathrm{pH}, \mathrm{EC}$ and maturity of the composting mixtures. Bioresour. Technol. 2001;78:301-308.

32. Amir S, Hafidi M, Merlina G, Revel JC. Sequential extraction of heavy metals during composting of sewage sludge. Chemosphere 2005;59:801-810.

33. Central Public Health and Environmental Engineering Organization. Manual on municipal solid waste management. New Delhi: Central Public Health and Environmental Engineering Organization; 2000.

34. Canadian Council of Ministers of the Environment. Guidelines for compost quality. Manitoba: Canadian Council of Ministers of the Environment; 1996. 